OPEN ACCESS

Edited by: Sgouris Sgouridis, Masdar Institute of Science and Technology, United Arab Emirates

Reviewed by: Xu Tang,

China University of Petroleum, China Dimitrios Angelopoulos, National Technical University of Athens, Greece Haris Doukas, National Technical University of Athens, Greece

${ }^{*}$ Correspondence:

Emanuele Facchinetti emanuele.facchinetti@hslu.ch

Specialty section:

This article was submitted to Energy Systems and Policy, a section of the journal Frontiers in Energy Research

Received: 26 April 2016

Accepted: 20 July 2016 Published: 04 August 2016

Citation:

Facchinetti E, Eid C, Bollinger $A$ and Sulzer S (2016) Business Model

Innovation for Local

Energy Management: A Perspective from Swiss Utilities.

Front. Energy Res. 4:31. doi: 10.3389/fenrg.2016.00031

\section{Business Model Innovation for Local Energy Management: A Perspective from Swiss Utilities}

\author{
Emanuele Facchinetti ${ }^{1 *}$, Cherrelle Eid ${ }^{2}$, Andrew Bollinger ${ }^{3}$ and Sabine Sulzer ${ }^{1}$ \\ 'Lucerne Competence Center for Energy Research, Lucerne University of Applied Science and Arts, Horw, Switzerland, \\ ${ }^{2}$ Faculty of Technology, Policy and Management, Delft University of Technology, Delft, Netherlands, ${ }^{3}$ Urban Energy Systems \\ Laboratory, EMPA, Dübendorf, Switzerland
}

The successful deployment of the energy transition relies on a deep reorganization of the energy market. Business model innovation is recognized as a key driver of this process. This work contributes to this topic by providing to potential local energy management (LEM) stakeholders and policy makers a conceptual framework guiding the LEM business model innovation. The main determinants characterizing LEM concepts and impacting its business model innovation are identified through literature reviews on distributed generation typologies and customer/investor preferences related to new business opportunities emerging with the energy transition. Afterwards, the relation between the identified determinants and the LEM business model solution space is analyzed based on semi-structured interviews with managers of Swiss utilities companies. The collected managers' preferences serve as explorative indicators supporting the business model innovation process and provide insights into policy makers on challenges and opportunities related to LEM.

Keywords: local energy management, energy hub, business models, business innovation, distributed generation, renewable energy

\section{INTRODUCTION}

The European ambitions for attaining sustainability targets are visible in the policies and measures deployed by the European Commission to achieve its 2020 and 2030 objectives for emissions reduction, energy efficiency, and increase in share of renewable energy (European Commission, 2012, 2014) and in the recent adoption of the Energy Union strategy (European Commission, 2015). However, in force EU policies will be insufficient to achieve the long-term target defined in the European Commission' Energy Road Map 2050 (European Commission, 2011). Countries leading the energy transition, such as Germany and Switzerland, adopted policies even more ambitious setting clear and long-term targets for 2050, including substantial reduction in primary energy consumption and carbon emission, increase of renewable energy share, and the phase out of nuclear power (BMWI, 2010; SFOE, 2013; Markard et al., 2015).

In this respect, a range of supportive energy policies, e.g., feed-in-tariffs and subsidies, favoring bottom-up investments in renewable energy and energy efficiency measures has been put in place (Anaya and Pollitt, 2015). Virtuous examples are the penetration of solar photovoltaic in

Abbreviations: LEM, local energy management. 
Germany (EPIA, 2014) and combined heat and power in many other European countries (Lund and Münster, 2006; Toke and Fragaki, 2008; Fragaki and Andersen, 2011). As a result of such policies, the increasing market penetration of distributed generation - based on renewables or favoring energy efficiency in fossil-based energy systems - is observed in many industrialized countries (IEA, 2014; Anaya and Pollitt, 2015) and is expected to significantly transform the energy supply value chain (Schleicher-Tappeser, 2012).

The intrinsic technological distinctness between distributed generation and traditional centralized generation is reflected on both the economic and organizational perspectives. As discussed by Schleicher-Tappeser (2012), distributed generation challenges traditional utility business models opening up new business opportunities to horizontal integrate diverse energy services - i.e., including electricity supply, cooling, heating, and additional energy-related services - and increasing autonomy and flexibility of customers. Such customer-oriented multi-services approaches require to be addressed by appropriate innovative business models. The capability, on the one hand, of policy makers to facilitate the transition with effective regulations and, on the other hand, of market players to develop successful business models will substantially affect the speed and effectiveness of the energy transition (Schleicher-Tappeser, 2012).

The role of business model innovation in supporting the required fundamental change of value proposition and value creation logic to generally promote the energy transition has been acknowledged by a number of recent scientific works. Loock (2012) reported the results of choice experiments with investment managers for renewable energy aiming to identify which business models could succeed in the market. The study showed that business models focusing on customers and proposing high-quality services are considered more attractive than business models oriented to low price and best technologies. Richter (2012) reviewed the existing business model approaches adopted by utilities with regard to renewable energy. The results showed that even though business models focusing on large projects insure a better risk-benefit compromise, utilities should urge to invest in business model innovation to take advantage of the forthcoming business opportunities related to smaller distributed generation projects. The same author (Richter, 2013b) analyzed the attitude of German utilities with respect to photovoltaic-based distributed generation and showed that utilities tended to fail perceiving photovoltaic generation as a new business opportunity and identified the causes behind this fact. Furthermore, it has been found that creating separated units within the company to address new businesses and to emphasize external partnerships can effectively foster the business model innovation process. The establishment of collaboration between distributed generation firms has been acknowledged as a key driver fostering business model innovation also by Hellström et al. (2015). In addition, the authors concluded that business models for distributed energy systems are not only the outcomes of a decision-making process across a certain number of options dictated by internal and external conditions but instead also a continuously active process aiming to keep the local business ecosystem profitable.
As presented in this concise literature review, the key role of business model innovation in fostering the energy transition has been described from different perspectives in the available scientific literature. Nevertheless clear gaps remain in the identification of specific business model patterns applicable in the energy transition context. Research addressing this topic has been initiated in a previous work presenting a heuristic methodology easing the identification of business model patterns best suited for local energy management (LEM) - the management of energy supply, demand and storage within a given geographical area (Facchinetti and Sulzer, 2016). Building upon the previously developed conceptual framework, the present contribution aims to specifically identify and explore the impact of the main determinants (or factors) that should be considered by stakeholders undertaking a business model innovation process for an intended LEM concept. First, the main determinants have been selected through the analysis of the existing scientific literature on distributed generation typologies and related customer/investor preferences. In a second step, the impacts of the identified determinants on the business model innovation process have been investigated via the implementation of semi-structured interviews with utility managers.

Utility companies, the focus of attention for this work, are on the edge of the energy transition and face the difficult challenge of innovating their business model in accordance with a very changing environment (Sühlsen and Hisschemöller, 2014). In particular, Swiss utilities, which have been involved in the present investigation, are currently exposed to a dual challenge. On the one hand, Switzerland is one of the countries leading the energy transition with its Energy Strategy 2050 (SFOE, 2013). On the other hand, Switzerland is still in the process of achieving full market liberalization. At the moment, locally established (city or canton level) utilities control the Swiss energy retail market. However, they are being prepared to face the upcoming full market liberalization.

The outcome of this study is a set of Swiss utility manager's preference indications providing an orientation toward the most appropriate business model pattern(s) to select for different LEM concepts. The present work represents a starting point toward the characterization of aspects driving the business model innovation process for LEM concepts.

The paper is organized as follows. In Section "Methodology," the applied conceptual framework and research methodology are described. In Section "Results," the results of the main determinants selection and interviews with utility managers are presented. The results are discussed in Section "Discussion." Finally, in Section "Conclusion," conclusions and policy implications are outlined.

\section{METHODOLOGY}

The applied methodological framework is depicted in Figure $\mathbf{1}$. In Section "The Conceptual Business Model Solution Space," the conceptual business model solution space for LEM developed in a previous work is summarized. In Section "The Selection of the Determinants," the methodology applied for the selection of the determinants is described. Finally, in Section "The Utility 


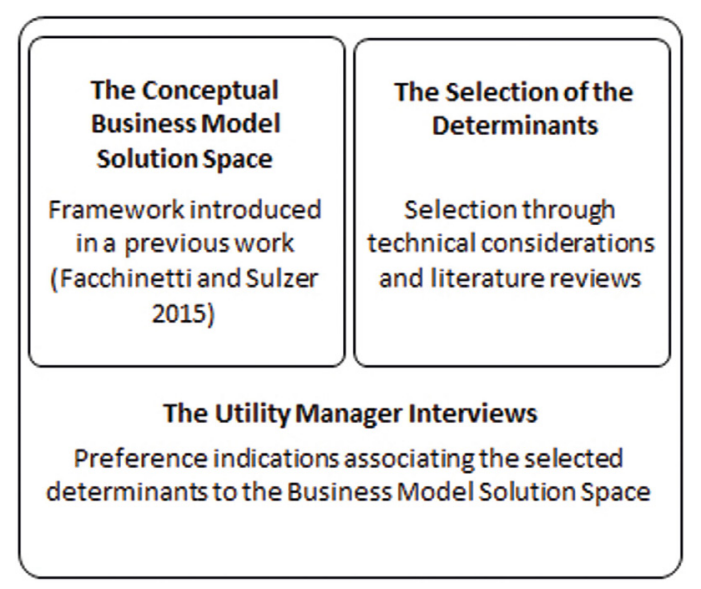

FIGURE 1 | Methodological framework.

Manager Interviews," the research approach applied for the manager's interviews is outlined.

Prior to describing the methodological framework, the considered definition of business model and business model innovation are here introduced. In this work, the term business model refers to the definition proposed by Osterwalder and Pigneur (2010): "the rationale of how an organization creates, delivers, and captures value." This definition is widely accepted within the literature and in particular in the energy sector (Okkonen and Suhonen, 2010; Richter, 2012; Facchinetti and Sulzer, 2016). Osterwalder and Pigneur fully characterize a business model based on four elements, namely the value proposition, describing the offer; the customers, characterizing the customer targets; the infrastructures, including all means required to deliver the value proposition; and, finally, the financial viability, explaining how profit is generated.

Business model innovation is defined as a discipline supporting the change of value proposition to customers (Bocken et al., 2014), involving the change of the way a business is run (Zott and Amit, 2013), and considering a large number of stakeholders and a broad value-network going well beyond the existing firm perspective (Beattie and Smith, 2013; Zott and Amit, 2013).

\section{The Conceptual Business Model Solution Space}

In a previous publication (Facchinetti and Sulzer, 2016), the authors developed a conceptual framework characterizing the LEM business model solution space. The conceptual framework supports LEM business model innovation offering a structured and comprehensive overview on available business model patterns. The business model pattern is defined as a portion of the solution space and it is characterized by a number of potentially applicable business model ideas organized with respect to the different steps of the LEM value chain. The business model ideas comprised in the selected business model solution space portion can be used to develop specific business models suitable to the intended LEM concept. In order to put into context and describe the defined solution space,
TABLE 1 | The business model reference patterns within the business model solution space (Facchinetti and Sulzer, 2016).

\begin{tabular}{|c|c|c|c|c|}
\hline & & \multicolumn{3}{|c|}{ Delivery of energy services } \\
\hline & & $\begin{array}{c}\text { Basic } \\
\text { services } \\
\text { (no frills) }\end{array}$ & $\begin{array}{c}\text { Tailored } \\
\text { services } \\
\text { (user } \\
\text { designed) }\end{array}$ & $\begin{array}{c}\text { High-quality } \\
\text { comprehensive } \\
\text { services } \\
\text { (experience } \\
\text { selling) }\end{array}$ \\
\hline \multirow{3}{*}{ 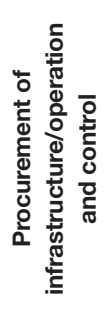 } & $\begin{array}{l}\text { Leasing to } \\
\text { customers (rent } \\
\text { instead of buying) }\end{array}$ & & \multirow{3}{*}{ Pattern II } & \multirow[t]{3}{*}{ Pattern III } \\
\hline & $\begin{array}{l}\text { Shared ownership } \\
\text { (fractional } \\
\text { ownership) }\end{array}$ & & & \\
\hline & $\begin{array}{l}\text { Customer } \\
\text { ownership } \\
\text { (orchestrator) }\end{array}$ & Pattern I & & \\
\hline
\end{tabular}

three reference patterns spanning across the solution space are defined and compared.

The business model solution space and the location of the three reference patterns are depicted in Table 1. The solution space is defined with respect to the available options on the procurement of infrastructures and on the delivery of energy services sides. On the procurement of infrastructures side, from the LEM perspective, the available options span from the customers owning infrastructures (Orchestrator), shared ownership between LEM and customers (Fractional Ownership), to leasing the LEM owned infrastructures to the customers (Rent instead of Buying). On the delivery of energy services side, the alternatives range from offering essential services (No Frills), offering customized services (User Designed), to offering comprehensive high-quality services (Experience Selling).

Following the business model definition of Osterwalder and Pigneur (2010), the key features characterizing the three reference business model patterns are presented in Table 2. The bottom line of Pattern I is to focus on the operation and control of third party owned infrastructures and to offer basic quality services to customers. In Pattern II, the LEM shares infrastructure ownership with the customers and offers them personalized solutions compatible with their own infrastructures and needs. Within Pattern III, the LEM offers to the customer the possibility to lease all-inclusive turnkey solutions, including high-quality services going beyond mere energy supply. For further details on the business model patterns and the business model ideas, refer to Facchinetti and Sulzer (2016).

\section{The Selection of the Determinants}

The first objective of the present work is the selection of the most relevant boundary conditions characterizing the business model innovation process. Such selected boundary conditions are defined as determinants. The determinants have been organized into three categories: (1) related to the LEM typology, including infrastructures and building characteristics; (2) related to customers, including socio-demographic aspects; and (3) related to the external determinants. Within each 
TABLE 2 | Main features of the identified reference business model patterns (Facchinetti and Sulzer, 2016).

\begin{tabular}{|c|c|c|c|c|}
\hline $\begin{array}{l}\text { Reference } \\
\text { business } \\
\text { model } \\
\text { patterns }\end{array}$ & \multicolumn{2}{|c|}{$\begin{array}{l}\text { Pattern I } \\
\text { (orchestrator- } \\
\text { no frills) }\end{array}$} & $\begin{array}{l}\text { Pattern II (fractional } \\
\text { ownership - user } \\
\text { designed) }\end{array}$ & $\begin{array}{l}\text { Pattern III } \\
\text { (rent instead } \\
\text { of buying - } \\
\text { experience selling) }\end{array}$ \\
\hline $\begin{array}{l}\text { Value } \\
\text { proposition }\end{array}$ & \multicolumn{2}{|c|}{$\begin{array}{l}\text { Multiside } \\
\text { platform } \\
\text { connecting } \\
\text { consumers, } \\
\text { prosumers, and } \\
\text { energy market }\end{array}$} & $\begin{array}{l}\text { Tailored energy } \\
\text { services adaptable } \\
\text { and complementary } \\
\text { to customer } \\
\text { infrastructures }\end{array}$ & $\begin{array}{l}\text { Comprehensive } \\
\text { turnkey solutions } \\
\text { going beyond } \\
\text { energy services }\end{array}$ \\
\hline Customers & \multicolumn{2}{|c|}{$\begin{array}{l}\text { Cost-sensitive } \\
\text { customers } \\
\text { Prosumers } \\
\text { owning the } \\
\text { infrastructures }\end{array}$} & $\begin{array}{l}\text { Customers } \\
\text { participating to } \\
\text { the infrastructure } \\
\text { investments }\end{array}$ & $\begin{array}{l}\text { Customers inclined } \\
\text { to pay higher prices } \\
\text { to get the best } \\
\text { service quality }\end{array}$ \\
\hline Infrastructures & \multicolumn{2}{|c|}{$\begin{array}{l}\text { No } \\
\text { investment on } \\
\text { infrastructures } \\
\text { Strong } \\
\text { partnerships }\end{array}$} & $\begin{array}{l}\text { Infrastructure } \\
\text { ownership shared with } \\
\text { customers }\end{array}$ & $\begin{array}{l}\text { Owned } \\
\text { infrastructures } \\
\text { leased to customers }\end{array}$ \\
\hline $\begin{array}{l}\text { Financial } \\
\text { viability }\end{array}$ & \multicolumn{2}{|c|}{$\begin{array}{l}\text { Revenues from } \\
\text { energy trading } \\
\text { only }\end{array}$} & $\begin{array}{l}\text { Revenues from energy } \\
\text { trading and service on } \\
\text { infrastructures }\end{array}$ & $\begin{array}{l}\text { Revenues from } \\
\text { energy trading, } \\
\text { leasing and } \\
\text { additional services }\end{array}$ \\
\hline \multicolumn{2}{|c|}{ Utility company } & \multicolumn{2}{|c|}{ Main area of operation } & enues 2014 (MCHF) \\
\hline \multicolumn{2}{|l|}{$\mathrm{BKW}$} & \multicolumn{2}{|c|}{ Bern Canton } & 2844 \\
\hline \multicolumn{2}{|l|}{ SIG } & \multicolumn{2}{|c|}{ Geneva Canton } & 1022 \\
\hline \multicolumn{2}{|l|}{ EWZ } & \multicolumn{2}{|c|}{ Zurich city } & 791 \\
\hline \multicolumn{2}{|c|}{ Groupe E } & \multicolumn{2}{|c|}{ Fribourg Canton } & 645 \\
\hline \multicolumn{2}{|c|}{ Romande Energie } & \multicolumn{2}{|c|}{ Vaud Canton } & 583 \\
\hline \multicolumn{2}{|l|}{ IBAARAU } & \multicolumn{2}{|l|}{ Aarau city } & 147 \\
\hline \multicolumn{2}{|l|}{ SHPOWER } & \multicolumn{2}{|c|}{ Schaffhausen Canton } & 112 \\
\hline \multicolumn{2}{|l|}{ EnergieThun } & \multicolumn{2}{|l|}{ Thun city } & 78 \\
\hline
\end{tabular}

category a number of determinants have been selected. The LEM typology determinants have been derived from technical considerations based on the available scientific literature on distributed generation typologies aiming to generally cover all possible LEM typologies. The review of the existing literature on customer and investor preferences related to new business opportunities emerging with the energy transition have supported the selection of, respectively, customer-related and external determinants.

\section{The Utility Manager Interviews}

In order to investigate the influence of the selected determinants on the business model innovation process, managers of utility companies have been involved in an explorative qualitative research approach. Explorative qualitative approaches are suitable to early stage research (Silvermann, 2009), such as the one on business models for the energy transition (Richter, 2013a).

Ten managers from eight among the largest Swiss utilities were involved. The eight utilities cover more than one-third of the Swiss energy retail market. The represented utility
TABLE 4 | Overview on selected main determinants and manager's preference indications.

\begin{tabular}{|c|c|c|c|}
\hline $\begin{array}{l}\text { Determinant } \\
\text { categories }\end{array}$ & Determinants & $\begin{array}{l}\text { Literature review } \\
\text { references }\end{array}$ & $\begin{array}{l}\text { Manager's } \\
\text { preference } \\
\text { indications }\end{array}$ \\
\hline \multirow[t]{5}{*}{ LEM typology } & $\begin{array}{l}\text { Project } \\
\text { typology }\end{array}$ & $\begin{array}{l}\text { Chicco and Mancarella (2009) } \\
\text { and Mancarella (2014) }\end{array}$ & Table 5 \\
\hline & $\begin{array}{l}\text { Density of } \\
\text { buildings }\end{array}$ & $\begin{array}{l}\text { Mancarella (2014) and Lund } \\
\text { et al. (2014) }\end{array}$ & Table 6 \\
\hline & $\begin{array}{l}\text { Buildings } \\
\text { typology }\end{array}$ & $\begin{array}{l}\text { Mancarella (2014) and Lund } \\
\text { et al. (2014) }\end{array}$ & Table 7 \\
\hline & $\begin{array}{l}\text { Energy } \\
\text { conversion } \\
\text { infrastructures }\end{array}$ & $\begin{array}{l}\text { Chicco and Mancarella (2009), } \\
\text { Orehounig et al. (2015), and } \\
\text { Fazlollahi et al. (2015) }\end{array}$ & Table 8 \\
\hline & $\begin{array}{l}\text { Self-sufficiency } \\
\text { level }\end{array}$ & $\begin{array}{l}\text { Chicco and Mancarella (2009), } \\
\text { Orehounig et al. (2015), and } \\
\text { Lasseter (2011) }\end{array}$ & Table 9 \\
\hline \multirow{3}{*}{$\begin{array}{l}\text { Customer } \\
\text { socio- } \\
\text { demographic }\end{array}$} & $\begin{array}{l}\text { Willingness to } \\
\text { pay }\end{array}$ & $\begin{array}{l}\text { Kaufmann et al. (2013) and } \\
\text { Sagebiel et al. (2014) }\end{array}$ & Table 10 \\
\hline & $\begin{array}{l}\text { Customer } \\
\text { awareness }\end{array}$ & $\begin{array}{l}\text { Curtius et al. (2012), } \\
\text { Kaufmann et al. (2013), and } \\
\text { Tabi et al. (2014) }\end{array}$ & Table 11 \\
\hline & $\begin{array}{l}\text { Building } \\
\text { ownership }\end{array}$ & $\begin{array}{l}\text { Sagebiel et al. (2014) and } \\
\text { Ebers and Wüstenhagen (2015) }\end{array}$ & Table 12 \\
\hline \multirow[t]{2}{*}{$\begin{array}{l}\text { External } \\
\text { determinants }\end{array}$} & Energy policy & $\begin{array}{l}\text { Provance et al. (2011), Yildiz } \\
\text { et al. (2015), Bürer and } \\
\text { Wüstenhagen (2009), and } \\
\text { Wüstenhagen and Menichetti } \\
\text { (2012) }\end{array}$ & Table 13 \\
\hline & Macro-economy & $\begin{array}{l}\text { Hofman and Huisman (2012), } \\
\text { Masini and Menichetti (2012), } \\
\text { and Masini and Menichetti } \\
\text { (2013) }\end{array}$ & Table 14 \\
\hline
\end{tabular}

companies are listed in Table 3 with their main area of operation and revenues. The managers were identified through their collaboration with the Swiss Competence Centers for Energy Research (Swiss Commision for Technology and Innovation, 2014), the Swiss national energy research program under which this project has been carried out. The participants included asset, business development, marketing, and product managers or directors ${ }^{1}$. The variety of the participant's business function and the differences in size and operational region of the represented companies ensured a representative and consistent sample suiting the explorative purposes of this qualitative analysis.

The managers were collectively invited to attend a workshop structured in two sessions. In a first common session, the managers were informed about the research project objectives and research methodology applied. In a second session, they were split into two groups and received a semi-structured questionnaire, including around 20 close-ended questions referring to the identified determinants. Going through the questionnaire, the moderators of each group introduced each question and confirmed in a preliminary discussion the understanding of the query. Afterwards each manager was asked to independently

${ }^{1}$ Two managers belonged to the upper management, seven to the middle management, and one to the lower management. 
provide his/her answer(s). The answers were first collected and then discussed to reveal the reasons behind the decisions ${ }^{2}$.

The data collected during the workshop were elaborated in three steps. The first step focused on the collection of the answers/ reasons per question across the two groups. In the second step, the answers for each question were compared and general trends were identified. In the third step, making use of the collected answer explanations, the identified trends were put into context and substantiated to derive preference indications specific to each determinant. The applied explorative qualitative research approach does not allow for drawing statistically relevant conclusions. The results of such data processing are presented in the next section.

\section{RESULTS}

This section explores the outcomes of the selection of the main determinants and of the utility managers interviews. The determinants are organized into three categories: related to the LEM typology, related to the socio-demographic characterization of customers, and related to external aspects. The identified determinants are summarized in Table 4.

Three sections focusing on each determinant category are presented hereafter. Within these sections, first, the selection of the specific determinants is discussed and each determinant characterized. Afterwards, the association of the determinants to the business model solution space, derived from the manager interviews, is outlined in form of preference indication (Tables 5-14).

\section{LEM Typology Determinants} Determinants Selection

This determinant category comprises the LEM typologyrelated features with a potential impact on the business model innovation process. In this respect, based on basic technical considerations and considering the available literature referring to distributed generation typologies (Chicco and Mancarella, 2009), including general concepts as smart grids (Mancarella, 2014), energy hubs (Orehounig et al., 2015), micro grids (Lasseter, 2011), and district energy systems (Lund et al., 2014;

${ }^{2}$ Answers and explanations are kept anonymous by request of the participants.

TABLE 5 | Project typology.

\begin{tabular}{|c|c|c|c|c|}
\hline & & \multicolumn{3}{|c|}{ Delivery of energy services } \\
\hline & & $\begin{array}{c}\text { Basic } \\
\text { services }\end{array}$ & $\begin{array}{l}\text { Tailored } \\
\text { services }\end{array}$ & $\begin{array}{l}\text { High-quality } \\
\text { comprehensive } \\
\text { services }\end{array}$ \\
\hline \multirow{3}{*}{ 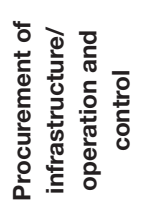 } & $\begin{array}{l}\text { Leasing to } \\
\text { customers }\end{array}$ & & & \multirow{3}{*}{$\begin{array}{c}\text { New } \\
\text { development } \\
\text { projects }\end{array}$} \\
\hline & $\begin{array}{l}\text { Shared } \\
\text { ownership }\end{array}$ & & \multirow{2}{*}{$\begin{array}{l}\text { Retrofit } \\
\text { projects }\end{array}$} & \\
\hline & $\begin{array}{l}\text { Customer } \\
\text { ownership }\end{array}$ & & & \\
\hline
\end{tabular}

Fazlollahi et al., 2015), the LEM typologies are classified with respect to the following characteristics: project type (Chicco and Mancarella, 2009; Mancarella, 2014), density of buildings (Lund et al., 2014; Mancarella, 2014), building typologies (Lund et al.,

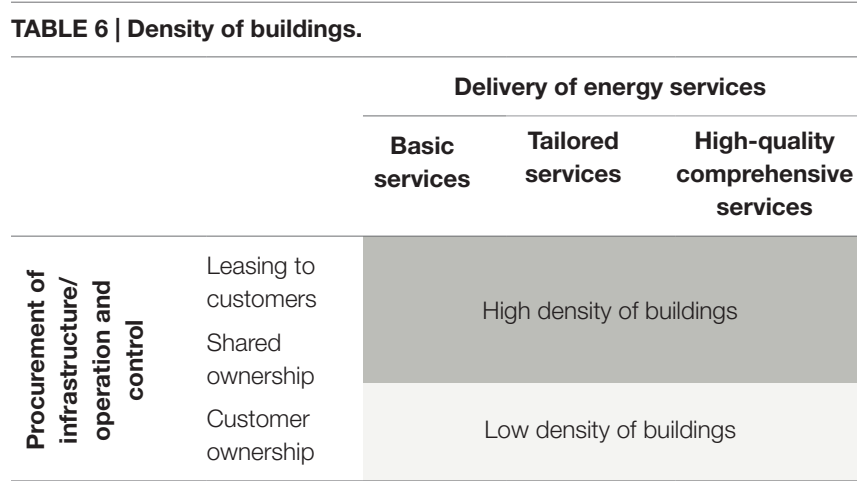

TABLE 7 | Buildings typology.

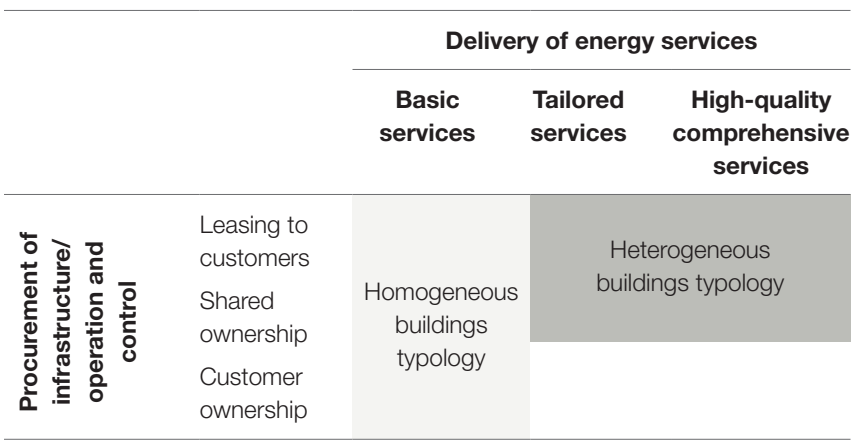

TABLE 8 | Energy conversion infrastructures.

\begin{tabular}{|c|c|c|c|c|}
\hline & & \multicolumn{3}{|c|}{ Delivery of energy services } \\
\hline & & $\begin{array}{c}\text { Basic } \\
\text { services }\end{array}$ & $\begin{array}{l}\text { Tailored } \\
\text { services }\end{array}$ & $\begin{array}{l}\text { High-quality } \\
\text { comprehensive } \\
\text { services }\end{array}$ \\
\hline \multirow{3}{*}{ 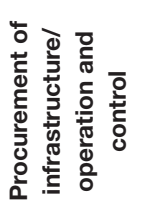 } & $\begin{array}{l}\text { Leasing to } \\
\text { customers }\end{array}$ & \multirow{3}{*}{$\begin{array}{l}\text { Single } \\
\text { energy } \\
\text { carrier }\end{array}$} & \multirow{2}{*}{\multicolumn{2}{|c|}{ Multi energy carriers }} \\
\hline & $\begin{array}{l}\text { Shared } \\
\text { ownership }\end{array}$ & & & \\
\hline & $\begin{array}{l}\text { Customer } \\
\text { ownership }\end{array}$ & & & \\
\hline
\end{tabular}

TABLE 9 | Self-sufficiency.

\begin{tabular}{|c|c|c|c|c|}
\hline & & \multicolumn{3}{|c|}{ Delivery of energy services } \\
\hline & & $\begin{array}{c}\text { Basic } \\
\text { services }\end{array}$ & $\begin{array}{l}\text { Tailored } \\
\text { services }\end{array}$ & $\begin{array}{l}\text { High-quality } \\
\text { comprehensive } \\
\text { services }\end{array}$ \\
\hline \multirow{3}{*}{ 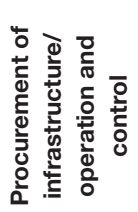 } & $\begin{array}{l}\text { Leasing to } \\
\text { customers }\end{array}$ & & \multirow{2}{*}{\multicolumn{2}{|c|}{ High self-sufficiency }} \\
\hline & $\begin{array}{l}\text { Shared } \\
\text { ownership }\end{array}$ & & & \\
\hline & $\begin{array}{l}\text { Customer } \\
\text { ownership }\end{array}$ & & & \\
\hline
\end{tabular}




\section{TABLE 10 | Willingness to pay.}

\begin{tabular}{|c|c|c|c|c|}
\hline & & \multicolumn{3}{|c|}{ Delivery of energy services } \\
\hline & & $\begin{array}{c}\text { Basic } \\
\text { services }\end{array}$ & $\begin{array}{l}\text { Tailored } \\
\text { services }\end{array}$ & $\begin{array}{c}\text { High-quality } \\
\text { comprehensive } \\
\text { services }\end{array}$ \\
\hline \multirow{3}{*}{ 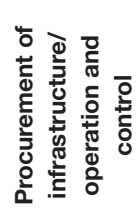 } & $\begin{array}{l}\text { Leasing to } \\
\text { customers }\end{array}$ & \multirow{3}{*}{$\begin{array}{c}\text { Price sensitive } \\
\text { customers }\end{array}$} & & \multirow{3}{*}{$\begin{array}{l}\text { Higher willingness } \\
\text { to pay customers }\end{array}$} \\
\hline & $\begin{array}{l}\text { Shared } \\
\text { ownership }\end{array}$ & & & \\
\hline & $\begin{array}{l}\text { Customer } \\
\text { ownership }\end{array}$ & & & \\
\hline
\end{tabular}

TABLE 11 | Customer awareness.

\begin{tabular}{|c|c|c|c|c|}
\hline & & \multicolumn{3}{|c|}{ Delivery of energy services } \\
\hline & & $\begin{array}{c}\text { Basic } \\
\text { services }\end{array}$ & $\begin{array}{l}\text { Tailored } \\
\text { services }\end{array}$ & $\begin{array}{c}\text { High-quality } \\
\text { comprehensive } \\
\text { services }\end{array}$ \\
\hline \multirow{3}{*}{ 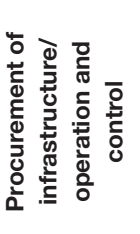 } & $\begin{array}{l}\text { Leasing to } \\
\text { customers }\end{array}$ & $\begin{array}{l}\text { Skeptical } \\
\text { customers }\end{array}$ & & \\
\hline & $\begin{array}{l}\text { Shared } \\
\text { ownership }\end{array}$ & & \multirow{2}{*}{\multicolumn{2}{|c|}{ Sustainability-oriented customers }} \\
\hline & $\begin{array}{l}\text { Customer } \\
\text { ownership }\end{array}$ & $\begin{array}{l}\text { Skeptical } \\
\text { customers }\end{array}$ & & \\
\hline
\end{tabular}

TABLE 12 | Building ownership.

\begin{tabular}{|c|c|c|c|c|}
\hline & & \multicolumn{3}{|c|}{ Delivery of energy services } \\
\hline & & $\begin{array}{c}\text { Basic } \\
\text { services }\end{array}$ & $\begin{array}{l}\text { Tailored } \\
\text { services }\end{array}$ & $\begin{array}{c}\text { High-quality } \\
\text { comprehensive } \\
\text { services }\end{array}$ \\
\hline \multirow{3}{*}{ 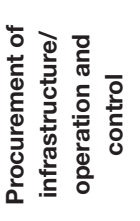 } & $\begin{array}{l}\text { Leasing to } \\
\text { customers }\end{array}$ & \multicolumn{3}{|c|}{ Real estates ownership } \\
\hline & $\begin{array}{l}\text { Shared } \\
\text { ownership }\end{array}$ & \multicolumn{2}{|c|}{ Cooperatives ownership } & \\
\hline & $\begin{array}{l}\text { Customer } \\
\text { ownership }\end{array}$ & \multicolumn{3}{|c|}{ House owners } \\
\hline
\end{tabular}

TABLE 13 | Energy Policy.

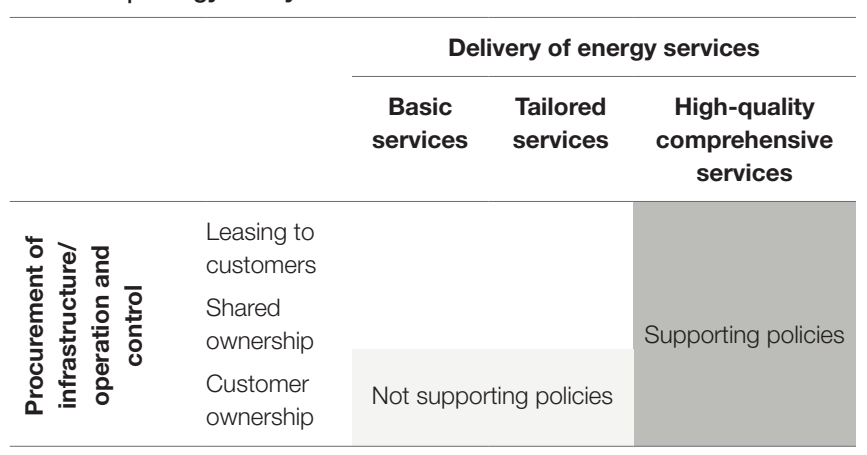

2014; Mancarella, 2014), energy conversion devices (Chicco and Mancarella, 2009; Fazlollahi et al., 2015; Orehounig et al., 2015), and self-sufficiency level devices (Chicco and Mancarella, 2009; Lasseter, 2011; Orehounig et al., 2015). In the following
TABLE 14 | Macro economy.

\begin{tabular}{|c|c|c|c|c|}
\hline & & \multicolumn{3}{|c|}{ Delivery of energy services } \\
\hline & & $\begin{array}{c}\text { Basic } \\
\text { services }\end{array}$ & $\begin{array}{l}\text { Tailored } \\
\text { services }\end{array}$ & $\begin{array}{l}\text { High-quality } \\
\text { comprehensive } \\
\text { services }\end{array}$ \\
\hline \multirow{3}{*}{ 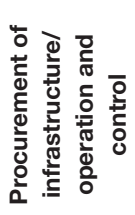 } & $\begin{array}{l}\text { Leasing to } \\
\text { customers }\end{array}$ & & & \multirow{3}{*}{$\begin{array}{c}\text { Stable } \\
\text { economic growth }\end{array}$} \\
\hline & $\begin{array}{l}\text { Shared } \\
\text { ownership }\end{array}$ & \multirow{2}{*}{\multicolumn{2}{|c|}{ Low economic growth }} & \\
\hline & $\begin{array}{l}\text { Customer } \\
\text { ownership }\end{array}$ & & & \\
\hline
\end{tabular}

paragraphs, the relevance of these features and the related derived preference indications on the business model pattern selection are outlined.

\section{Determinants Exploration \\ Project Typology}

Local energy management can be integrated and operate either in a completely new district project or in a retrofit project of an existing district. Although in both cases the implementation objectives are the same - to maximize the energy efficiency, sustainability, and profitability of the energy system - the challenges faced are clearly different. Developing the energy concept from scratch allows considering a larger amount of options, whilst adapting to the existing situation bears more constraints and uncertainties. New LEM projects can benefit from a potentially higher energy efficiency performance and flexibility levels that can lead to higher profitability for the same investment compared to retrofit projects. The latter must be developed selecting complementary infrastructures complying with existing (not optimized) technical infrastructures heterogeneously operated and owned by different customer typologies.

The managers generally agreed that tailored business models specifically addressing the particular requirements of the various involved stakeholders are required to overcome the additional barriers typically characterizing retrofit projects. For this reason, they expect retrofit projects to take advantage of business model approaches involving the customers in the infrastructure procurements and/or operation (Preference indication: Retrofit projects, Table 5). Conversely, manager's opinion is that, since new projects can be addressed more flexibly, they potentially appear as more appropriate and financially attractive also to external large investors completely or partially taking over the procurement and operation of the infrastructures. Due to the lack of pre-existing technical and legally binding agreements with the customers, they substantially agreed that the valorization of comprehensive high-quality solutions is easier in new projects (Preference indication: New development projects, Table 5).

\section{Density of Buildings}

The density of buildings within the LEM operation area represents an influential aspect driving the development especially of LEM concepts dealing with thermal and chemical energy networks. Infrastructure costs and energy losses related to the energy 
services distribution increase significantly when the customers' and partners' density decrease. Districts can be categorized with three typical density levels: high density, typical of city's districts; moderate density, typical of suburban districts; and low density, typical of rural districts.

High-density districts can profit from reduced energy losses and need for distribution infrastructures. For these reasons, the managers argued that, on the one hand, high-density districts can offer higher profitability potential to the LEM investors and so be suitable to leasing solutions. On the other hand, they also offer opportunity for centralized infrastructures (e.g., district heating), characterized by long term, large investments and, thus, more appropriate to business models based on shared ownership (Preference indication: High density of buildings, Table 6). The fact that moderate and low-density districts are penalized by distribution costs and attract smaller investments in distributed heat, cooling, and storage infrastructures explains the managers inclination toward business models favoring customer ownership for such districts (Preference indication: Low density of buildings, Table 6). No preference has been highlighted on the quality level of energy services to be provided.

\section{Buildings Typology}

The LEM buildings typology has a significant impact on both technical and business model developments. Buildings typologies generally include residential buildings, commercial buildings, industry, and farms. Energy demand and generation profiles of these typologies are very heterogeneous in time, quantity, and flexibility. The development of business models tailored to the customer energy requirements and flexibility is the main driver to maximize the LEM profitability. Within cities a high share of residential and commercial buildings is more likely. In suburban and rural areas, the relevance of industry and farms rises substantially. Heterogeneous customers and partners enable the LEM to operate across various energy demand/load profiles and, thus, potentially to have more internal flexibility opportunities to valorize. Consequently, a LEM operating across more diverse building typologies is expected to require smaller investments in infrastructure to achieve the same levels of profitability and energy independence.

The managers converged on the idea that business models offering tailored service solutions on both the ownership and quality of services perspectives should address very heterogeneous customer portfolios. In particular, they argued that leasing solutions and high-quality comprehensive services should be considered for this scenario characterized by higher complexity and profitability potential (Preference indication: Heterogeneous buildings typology, Table 7). Evaluating the homogeneous customer portfolio scenario, the managers expressed a preference toward basic services and multiple infrastructure ownership options. The idea behind this choice is to provide a limited number of standardized services to a large number of similar customers, while leaving all options open on the infrastructure ownership side (Preference indication: Homogeneous buildings typology, Table 7).

\section{Energy Conversion Infrastructures}

A LEM could generally operate energy conversion and storage infrastructures across multiple energy carriers, including electrical, thermal, and chemical carriers. Distributed generation implies a mix of customer-sited energy conversion devices (e.g., photovoltaic panels, boilers) and centralized plants (e.g., combined heat and power plants, power to gas plants). Different combinations of devices enable different combinations of energy consumption, generation, and storage. Furthermore, each infrastructure can be used, operated, and owned by different entities. The increased complexity of the technical architecture with respect to traditional decoupled single energy carrier energy systems is also reflected on the business model structure. LEM business models should capitalize on the economic value of the flexibility offered by operating across different energy carriers, while maintaining the level of clarity and transparency associated with traditional single energy carrier business models.

The managers were asked to provide their opinion on LEM scenarios, including single or multiple energy carriers. Evaluating the multiple energy carriers' case, the managers argued that the more complex the LEM infrastructure, the larger the required investments and the higher should be the profitability. For this reason, the majority of the managers favored business models focusing on procurement of infrastructures and on the creation of added value through offering high-quality comprehensive and tailored services. They considered these business model approaches to be the most suitable to address the higher investment risks and related higher profitability characterizing multiple energy carrier scenarios (Preference indication: Multi energy carriers: Table 8). Conversely, they evaluated simpler LEM scenarios, including only a single energy carrier as conveniently associable with business models providing basic services and attracting a larger number of customers through the offering of different ownership solutions (Preference indication: Single energy carrier: Table 8).

\section{Self-Sufficiency Level}

The LEM self-sufficiency level defines the LEM dependency on the external energy market. This feature is closely related to the energy conversion infrastructures available: a high selfsufficiency level is likely to require investments in infrastructures complementary to the ones contributed by the customers. On the other hand, self-sufficiency represents an additional value proposition to the customer, a self-sufficient LEM could offer: reduced exposure to the external determinants influencing the prices on the wholesale energy market; and certified local origin and quality (i.e., renewable share) of the provided energy services.

The managers generally appeared rather skeptical of the possibility of self-sufficient LEM due to techno-economic constraints. However, following the same logic applied when evaluating multi-energy carriers scenarios, they agreed that LEM characterized by high self-sufficiency levels should be favorably addressed by business models targeting customers willing to pay the extra price of the provided added values and optionally willing to participate to the infrastructure investment (Preference indication: Self-sufficiency level, Table 9). 


\section{Customer Socio-Demographic Determinants \\ Determinants Selection}

Many recent publications have addressed the characterization of customer's segments with respect to new business opportunities emerging with the energy transition. A concise literature review is presented hereafter. The outlined findings enable identification of the most important determinants related to socio-demographic aspects to be considered in the business model innovation process.

Curtius et al. (2012) explored the customer segmentation for smart grids on the basis of a European study and derived a number of generic business models best suited to address the different customer segments. This work highlighted that no single business model can guarantee the successful penetration of smart grids. Instead various business models characterized by optimized value propositions matching the heterogeneous customer values perceptions should be developed. Three different customer segments have been identified: The Supporters, including customers across all ages strongly supporting smart grids; The Ambiguous, characterized mainly by young customers willing to support smart grid diffusion but also concerned by data security issues; and The Skeptical, including mainly older customers not particularly concerned by environmental problems and expecting small benefits from smart grid.

Kaufmann et al. (2013) investigated the preference for smart metering of private consumers in Switzerland. Using conjoint analysis they assessed, on the one hand, the overall willingness of customers to pay for smart meters and, on the other hand, the existence of four customer segments with significantly different value perception: the risk averse, including customers not convinced on the benefit from smart meters; the technology minded, including customers perceiving a high value from smart metering; the price sensitive, including customers strongly concerned by the price and interested to reduce their costs with smart meters; and the safety oriented, including customers attracted by the values offered by smart meters associated with home security. As an outcome, the heterogeneity of customers in terms of value perception encourages the offering of different tailored value propositions rather than a standard offer for the whole market.

Tabi et al. (2014) investigated the differences between customers adopting renewable energy and potential adopters. Through conjoint analysis, a different customer segmentation has been identified based on customers' preferences concerning electricity products. Although a large majority of customers demonstrated clear preferences for renewable energy, only a small fraction purchased it. The study showed that demographic variables play a minor role, while a significantly higher education level appears as key driver. Psychographic and behavioral factors have a strong impact on the choice of adopting renewable energy. The identified aspects that should influence potential adopters are: the preference for locally produced electricity, the sensitivity to increases in the cost of electricity, and the reduced awareness on environmental issues.

Sagebiel et al. (2014) showed how in Germany customers have a slightly higher willingness to pay for renewable electricity produced within cooperatives. In particular, customers appears to be mainly attracted by the fact that electricity from a cooperative is produced from renewable resources and to a smaller extent they value the facts that this electricity is produced locally, democratically, and transparently.

Ebers and Wüstenhagen (2015) investigated the investment decision-making with respect to different financing options for renewable energy projects of consumers in Switzerland. The result of the analysis highlighted the existing market potential for new financial products, such as community finance projects and retirement investment funds. Furthermore, the analysis showed how homeowners would preferably rely on their own funds to finance a renewable energy installation or to make use of mortgage and only to a minor extent they consider loan and leasing solutions.

Customer's socio-demographic aspects appear to play a major and complex role in determining their preferences. The strong correlation between these variables is reflected in very heterogeneous customer's preferences and perceptions. Effective business models should cope with the consequent large customer segmentation offering more flexible and tailored solutions than in traditional energy-related business models. Based on the presented literature review, three main determinants related to customer socio-demographic aspects are selected: willingness to pay (Kaufmann et al., 2013; Sagebiel et al., 2014); customer awareness (Curtius et al., 2012; Kaufmann et al., 2013; Tabi et al., 2014); and building ownership (Sagebiel et al., 2014; Ebers and Wüstenhagen, 2015). These three determinants are explored hereafter.

\section{Determinants Exploration Willingness to Pay}

In traditional energy-related business models, little or no attention is paid to differentiating the offers addressing customers with different willingnesses to pay. The required new business models, focusing on services and potentially including the procurement of infrastructures value chain activity, should flexibly target customer segments characterized by all levels of investment potential and price sensitivity.

In this regard, the managers generally agreed on the need to develop flexible business models offering adequate financial instruments and basic services to be offered to price-sensitive customers and to customers with reduced possibility to invest in owned infrastructures (Preference indication: Price sensitive customers, Table 10). Conversely, customers with higher willingness to pay should be attracted by high-quality service packages and different options of investments opportunities (Preference indication: Higher willingness to pay customers, Table 10).

\section{Customer Awareness}

The awareness and consciousness of environmental issues is expected to play a significant role on the energy transition process and is a key aspect to be considered while developing LEM business models.

The managers suggested that customers particularly concerned by energy transition and environmental issues are more prone to engage in investments in the required infrastructures. 
Moreover, they agreed that such customers should be addressed with offers, including more than basic services (Preference indication: Sustainability oriented customers, Table 11). At the opposite end, conservative-minded customers, skeptical of the energy turnaround and of new technologies, are expected to require only the basic traditional services and to favor either the traditional approach of owning the required infrastructures or the option to lease it (Preference indication: Skeptical customers, Table 11).

\section{Building Ownership}

Local energy management could operate across privately owned, real estates and cooperative owned buildings. The building ownership is an important aspect to consider while developing successful business models. Real estate investors, private house owners, and cooperatives represent highly diversified customer segments.

The managers presumed that private owners would be interested in investment opportunities in owned infrastructure and in its potential valorization within the energy market. For this reason, they agreed on suggesting business models focusing on customer ownership. No preferences were indicated on the quality level of energy services to be provided (Preference indication: House owners, Table 12). With respect to cooperatives, the managers agreed on the fact that business models based on shared ownership and including basic or tailored solutions are likely to be the most appropriate. Real estates are expected to favor a range of different quality level leasing solutions, which could be offered to their tenants (Preference indication: Real estates ownership, Table 12).

\section{External Determinants Determinants Selection}

Innovative entrepreneurial approaches, such as the one required by the energy transition, strongly rely on external investors. Understanding investor preferences and the drivers behind their decision-making process represents an additional key driver for the development of appealing business models with a higher probability to succeed. A number of recent studies investigating investor preferences on the renewable energy sectors are available in the literature.

Studying the microgeneration sector, Provance et al. (2011) highlighted that in strongly institutionalized markets, such as energy, business models innovation is driven not only by resolute decision-making based on available internal values but also on local external determinants, such as politico-institutional and socio-institutional aspects. Yildiz (2014) investigated the business models fostering financial citizen participation in investments in renewable energy infrastructures in Germany. The study highlights the importance of coordinating the development of new business models and new policies in fostering private contribution to renewables investment.

Bürer and Wüstenhagen (2009) analyzed the policy preferences of private investors in clean tech companies in Europe and North America. By interviewing 60 venture capital and private equity investors, they assessed the overall preference for feed-in tariffsbased policies. Feed-in tariffs appeared to be more effective in reducing investment risks than trading mechanism policies, such as green certificates. An additional outcome was that investors agreed on the need for a mix of consistent policies to stimulate interest in investment in clean technology. Hofman and Huisman (2012) repeated part of the same survey 3 years later in order to analyze the impact of the economic crisis on investor preferences. The study highlighted that generally the popularity of energy policies has decreased especially on policies involving subsidies and trade schemes and on European investors. However, feed-in tariffs remained the preferred option.

Masini and Menichetti $(2012,2013)$ investigated the decisionmaking process of investors in renewable energy technologies in the context of the current global economic crisis. Investors' preferences on policy instruments and technological risks were analyzed. The results revealed how investors value more the proven technical reliability of a technology than its market efficiency, since market efficiency can be influenced by policy measures. Furthermore, the analyses identified a segment of investors strongly preferring short-term policies providing high financial incentives than long-time policies characterized by lower financial support. Wüstenhagen and Menichetti (2012) discussed the relation between the strategic decision process for renewable energy investments and energy policies. The authors outlined the need for a segmentation of energy policies to support and promote the heterogeneous segmentation of investors characterizing the renewable energy market.

Existing literature highlighted the strong influence of external determinants on investors preferences and, thus, on business model development. Based on the literature analysis, energy policy (Bürer and Wüstenhagen, 2009; Provance et al., 2011; Wüstenhagen and Menichetti, 2012; Yildiz et al., 2015) and macroeconomy (Hofman and Huisman, 2012; Masini and Menichetti, 2012, 2013) are selected as the main external determinants to be considered. The description of these two determinants and the related preference indications derived from the utility manager opinions are outlined in the following paragraphs.

\section{Determinants Exploration \\ Energy Policy}

Policy makers regulate the energy transition's evolving pace through market regulations, subsidies (on fossil fuel and/or renewable energies), as well as taxes (e.g., carbon tax). Timelength, typology, and amplitude of the financial incentives together with the level of clarity and stability of the political strategy are the main factors influencing potential investor decisions.

Supporting energy policies frameworks characterized by short-term high financial incentives are the most attractive for small to large investors. The managers expected this scenario to be suitable to business models open to all infrastructures ownership options and focusing on high-quality comprehensive services (Preference indication: Supporting policies, Table 13). Considering an uncertain energy policy framework, such as those mostly charactering the current phase of the energy transition, the managers indicated that large investments are discouraged and, thus, business models favoring customer ownership and relying on basic or tailored energy services are the most preferred (Preference indication: Not supporting policies, Table 13). 


\section{Macro-Economy}

The macro-economic situation, including growth or recession cycles, interest rates, and inflation levels, has a significant impact on investors' behavior in any market. The typically large and longterm investments required in the energy sector accentuate the influence of this determinant.

In uncertain low growth macro-economic scenarios characterized by low inflation and low interest rates, such as the current global economic situation, business models oriented to customer or shared ownerships were indicated as most suitable due to their compatibility toward both small private and large public investments (Preference indication: Low economic growth, Table 14). Conversely, the managers expected that large investors would become protagonists in more favorable economic conjunctures, characterized by stable growth and high interest rates. For this case, they suggested business models providing high-quality services and characterized by higher investments and potential profitability (Preference indication: Stable economic growth, Table 14).

\section{DISCUSSION}

For most of the investigated determinants, the managers provided agreeing or at least compatible answers. The reasons behind their choices were sometimes more heterogeneous, showing how the different perspectives related to their different job functions and experiences played an important role. Combining answers and explanations enabled the recognition of leading general trends pointing to more or less specific portions of the business model solution space.

Especially at the beginning of the semi-structured interviews, the managers struggled to cope with the proposed approach of investigating each determinant independently. They highlighted the fact that - the identified determinants being to a certain extent correlated to each other - it is challenging to generally judge the impact of each one separately. Nevertheless, once the managers became familiar with the proposed approach they acknowledged the advantage of focusing on a single aspect at time. This reduces the unsuitable attitude of associating existing combination of determinants to traditional business model approaches. Instead it forces broad re-examination of each determinant to identify unexplored options.

The analysis of possible correlations/dominances between different determinants is an interesting aspect to be addressed in future investigations. A better understanding of these dependencies would further strengthen the ability of the conceptual framework to support business model innovation.

Also, during the discussion, the managers highlighted the difficulty that they are currently experiencing in switching from the continuous adaptation of their traditional long established business models, which focus on infrastructures and feature little or no consideration of customer preferences, toward the creation of innovative customer-oriented business models. The related challenge is threefold. First, it entails the identification of economically viable new business opportunities in a changing market and policy framework. Second, it requires the organization of the new indispensable activities of collecting, monitoring, and understanding customer preferences. Third, it demands the development from scratch of the business models required to exploit the broader variety of emerging business opportunities and customer segments. With respect to the last point, the managers praised the possibility offered by the proposed conceptual framework to provide a comprehensive and organized solution space favoring a systematic approach to initiate the business model innovation process. Furthermore, they valued the proposed research work aiming to provide an orientation within said conceptual framework through the identification and characterization of major determinants.

Going generally across the provided preference indications, it appears that when the business conditions are favorable (e.g., growing economy, high willingness to pay of customers, high density of buildings), the managers generally orient their preferences toward business models focusing on comprehensive high-quality services. Conversely, when conditions are not encouraging, the preference goes toward basic or tailored services often in combination with customer ownership of infrastructures. This confirms that the current economic and political situation favors business models oriented to customer ownership and basic or tailored services (Facchinetti and Sulzer, 2016). Assuming that the next steps of the energy transition are characterized by a more suitable and less uncertain regulatory framework, business models offering customer-oriented high-quality services and infrastructure leasing solutions are expected to attract more and more attention from utilities. Improved macro-economic conditions would accelerate this trend. From this general perspective, the role of shared ownership approaches appears controversial. The managers rarely indicated individual preference for these approaches; instead they mostly suggested them as an alternative/complementary option to LEM ownership approaches. This evidence could be explained by the fact that these business approaches have proven their market success in the context of the energy transition in public or cooperatives businesses (Viardot, 2013; Yildiz et al., 2015). However, so far they have not been at the core of the utilities' market strategy (Richter, 2013a).

Clearly, the present work bears limitations that should be considered. The fact that the analysis has been restricted to a very specific empirical context and to a limited sample of managers makes the outcomes difficult to generalize. The applied explorative qualitative research approach is not meant to derive exhaustive and general conclusions, but instead to provide a first contribution to understanding the link between business model innovation and stakeholder preferences at this stage of the energy transition. We expect to address in follow-up works the further consolidation, refinement, and extension of the proposed preference indications through a deeper analysis involving a larger number and variety of stakeholders.

\section{CONCLUSION}

The effective accomplishment of the energy turnaround relies on a deep reorganization of the energy market. Business model innovation is recognized as a key driver of this process. The present paper contributes to this topic by providing to stakeholders 
and policy makers an orientation within the vast business model solution space of LEM concepts - defined as the management of energy supply, demand, and storage within a given geographical area. The contribution of the present work to the existing literature on business model innovation for the energy transition is twofold. First, based on comprehensive literature reviews, it provides a structured selection of main factors to be considered by stakeholders undertaking a business model innovation process for an intended LEM concept. Second, based on interviews with utility managers it provides indications for the identification of specific business model patterns most appropriate to valorize LEM.

Building upon a recent previous work (Facchinetti and Sulzer, 2016) in which the LEM business model solution space was characterized through the definition of a conceptual framework, the present work goes one step further. The main determinants to be considered within the business model innovation process have been selected through reviews on distributed generation typologies and customer/investor preferences related to new business opportunities emerging with the energy transition. The identified determinants have been organized into three categories: related to the LEM typology, related to customer characterization, and related to external aspects.

The impact of the identified determinants on the business model innovation process has been investigated through an explorative qualitative research approach collecting the opinions of Swiss utility managers through semi-structured interviews. The outcome of this study is a set of preference indications associating the identified determinants with the most suitable region of the LEM business model solution space (Tables 5-14).

The interviews confirmed existing literatures (Richter, 2013b; Helms, 2016) and shed light on the challenge that the utility managers are currently facing: discontinuing the adaptation of traditional long established business models, focusing on infrastructures and with little or no customer preferences consideration, in favor of pursuing new business models built around customers' needs and preferences. From this perspective, the managers acknowledged the support offered by the proposed systematic and comprehensive conceptual framework for LEM business model innovation.

The provided conceptual framework offers to potential LEM stakeholders a structured guide through the business model innovation process. Characterizing the intended LEM with regard to the determinants identified in this work, and then following the corresponding preference indications, would lead stakeholders to the most appropriate portion(s) of the business model solution space in accordance with the utility manager's preferences. Each solution space portion is characterized by clusters of generic business model ideas referring to the different LEM value chain steps (Facchinetti and Sulzer, 2016). Through combination and adaptation of the identified business model ideas, stakeholders can develop suitable business models tailored to the intended LEM concept.

Policy makers could take advantage of the presented conceptual framework by using it to understand and predict a
LEM stakeholder's decision-making process in a comprehensive variety of scenarios. Analyzing the impact factors influencing the business model innovation process should ease the determination of outdated policies hindering the penetration of innovative business approaches, and accelerate the development of a more segmented and flexible regulatory framework appropriate to favoring LEM market penetration.

The following main outcomes have been derived from the managers' preference indications. The utility managers appeared generally inclined to favor business models focusing on high-quality comprehensive services when business conditions are favorable. The mentioned favorable business conditions include supportive policies scenarios, a growing economy, new development projects involving multiple energy carriers in areas characterized by a high building density, and target customers with a high willingness to pay. When conditions are more adverse, the manager's preferences are generally oriented toward business models relying on basic or tailored services, often in combination with customer ownership of infrastructures. This evidence suggests that in the current political and economic situation business models focusing on customer ownership and basic or tailored services are preferred. This conclusion confirms previous findings based on a market analysis (Facchinetti and Sulzer, 2016). In other ways, assuming movement toward a more suitable and less uncertain regulatory framework, business models focusing on customer-oriented high-quality services and infrastructure leasing solutions should attract more and more attention from the utilities. From this perspective, in order to increase the appeal of LEM to large investors, policy makers should develop suitable regulatory frameworks guaranteeing consistent and stable policies across a time period compatible with the long-term investment required. Finally, the analysis has shown that, in the view of utility managers, the role of business models characterized by shared ownership approaches is controversial. Indeed, the managers rarely indicated individual specific preference for such approaches. Considering the intrinsic suitability of shared ownership approaches to LEM concepts, policy makers should encourage such approaches so far only to a minor extent addressed by the legislation and applied in the energy market.

\section{AUTHOR CONTRIBUTIONS}

EF: main author, main contribution to the conception of the work. $\mathrm{CE}, \mathrm{AB}$, and SS: significant contribution to the conception and critical revision of the work.

\section{ACKNOWLEDGMENTS}

This work has been accomplished in the frame of the Swiss Competence Center for Energy Research on Future Energy Efficient Buildings \& Districts SCCER FEEB\&D, funded by The Commission for Technology and Innovation of the Swiss Confederation. The authors are particularly grateful to the utility companies that kindly accepted to participate to this study. 


\section{REFERENCES}

Anaya, K. L., and Pollitt, M. G. (2015). Integrating distributed generation: regulation and trends in three leading countries. Energy Policy 85, 1-12. doi:10.1016/j. enpol.2015.04.017

Beattie, V., and Smith, S. J. (2013). Value creation and business models: refocusing the intellectual capital debate. Br. Account. Rev. 45, 243-254. doi:10.1016/j. bar.2013.06.001

Bundesministerium für Wirtschaft und Technologie (BMWi). (2010). Energiekonzept. Available at: https://www.bmwi.de/BMWi/Redaktion/PDF/E/ energiekonzept-2010, property $=$ pdf, bereich $=$ bmwi2012, prache $=$ de, $r w b=$ true.pdf

Bocken, N. M. P., Short, S. W., Rana, P., and Evans, S. (2014). A literature and practice review to develop sustainable business model archetypes. J. Clean. Prod. 65, 42-56. doi:10.1016/j.jclepro.2013.11.039

Bürer, M. J., and Wüstenhagen, R. (2009). Which renewable energy policy is a venture capitalist's best friend? Empirical evidence from a survey of international cleantech investors. Energy Policy 37, 4997-5006. doi:10.1016/j. enpol.2009.06.071

Chicco, G., and Mancarella, P. (2009). Distributed multi-generation: a comprehensive view. Renew. Sustain. Energy Rev. 13, 535-551. doi:10.1016/j.rser.2007.11.014

Curtius, H. C., Künzel, K., and Loock, M. (2012). Generic customer segments and business models for smart grids. der markt 51, 63-74. doi:10.1007/ s12642-012-0076-0

Ebers, A., and Wüstenhagen, R. (2015). 5th Consumer Barometer of Renewable Energy in Cooperation with Raiffeisen. Available at: http://www.iwoe.unisg. $\mathrm{ch} /$ /media/internet/content/dateien/instituteundcenters/iwoe/news/150522 kundenbarrometer2015_e_web.pdf?fl=en

EPIA. (2014). Global Market Outlook for Photovoltaics 2014-2018. Brussels. Available at: http://www.cleanenergybusinesscouncil.com/site/resources/files/reports/ EPIA_Global_Market_Outlook_for_Photovoltaics_2014-2018_-_Medium_ Res.pdf

European Commission. (2011). COM/2011/0885 Energy Roadmap 2050. Brussels

European Commission. (2012). Directive 2012/27/EU of the European Parliament and of the Council of 25 October 2012 on Energy Efficiency. Brussels

European Commission. (2014). COM/2014/015 A Policy Framework for Climate and Energy in the Period from 2020 to 2030. Brussels

European Commission. (2015). COM/2015/080 A Framework Strategy for a Resilient Energy Union with a Forward-Looking Climate Change Policy. Brussels

Facchinetti, E., and Sulzer, S. (2016). General business model patterns for local energy management concepts. Front. Energy Res 4, 7. doi:10.3389/fenrg. 2016.00007

Fazlollahi, S., Becker, G., Ashouri, A., and Maréchal, F. (2015). Multi-objective, multi-period optimization of district energy systems: IV - A case study. Energy 84, 365-381. doi:10.1016/j.energy.2015.03.003

Fragaki, A., and Andersen, A. N. (2011). Conditions for aggregation of CHP plants in the UK electricity market and exploration of plant size. Appl. Energy 88, 3930-3940. doi:10.1016/j.apenergy.2011.04.004

Hellström, M., Tsvetkova, A., Gustafsson, M., and Wikström, K. (2015). Collaboration mechanisms for business models in distributed energy ecosystems. J. Clean. Prod. 102, 226-236. doi:10.1016/j.jclepro.2015.04.128

Helms, T. (2016). Asset transformation and the challenges to servitize a utility business model. Energy Policy 91, 98-112. doi:10.1016/j.enpol.2015. 12.046

Hofman, D. M., and Huisman, R. (2012). Did the financial crisis lead to changes in private equity investor preferences regarding renewable energy and climate policies? Energy Policy 47, 111-116. doi:10.1016/j.enpol.2012.04.029

IEA. (2014). World Energy Outlook 2014.

Kaufmann, S., Künzel, K., and Loock, M. (2013). Customer value of smart metering: explorative evidence from a choice-based conjoint study in Switzerland. Energy Policy 53, 229-239. doi:10.1016/j.enpol.2012.10.072
Lasseter, R. H. (2011). Smart distribution: coupled microgrids. Proc. IEEE 99, 1074-1082. doi:10.1109/JPROC.2011.2114630

Loock, M. (2012). Going beyond best technology and lowest price: on renewable energy investors' preference for service-driven business models. Energy Policy 40, 21-27. doi:10.1016/j.enpol.2010.06.059

Lund, H., and Münster, E. (2006). Integrated energy systems and local energy markets. Energy Policy 34, 1152-1160. doi:10.1016/j.enpol.2004.10.004

Lund, H., Werner, S., Wiltshire, R., Svendsen, S., Thorsen, J. E., Hvelplund, F., et al. (2014). 4th Generation district heating (4GDH). Energy 68, 1-11. doi:10.1016/j. energy.2014.02.089

Mancarella, P. (2014). MES (multi-energy systems): an overview of concepts and evaluation models. Energy 65, 1-17. doi:10.1016/j.energy.2013.10.041

Markard, J., Suter, M., and Ingold, K. (2015). Socio-technical transitions and policy change - Advocacy coalitions in Swiss energy policy. Environ. Innov. Soc. Transit 18, 215-237. doi:10.1016/j.eist.2015.05.003

Masini, A., and Menichetti, E. (2012). The impact of behavioural factors in the renewable energy investment decision making process: conceptual framework and empirical findings. Energy Policy 40, 28-38. doi:10.1016/j.enpol. 2010.06.062

Masini, A., and Menichetti, E. (2013). Investment decisions in the renewable energy sector: an analysis of non-financial drivers. Technol. Forecast. Soc. Change 80, 510-524. doi:10.1016/j.techfore.2012.08.003

Okkonen, L., and Suhonen, N. (2010). Business models of heat entrepreneurship in Finland. Energy Policy 38, 3443-3452. doi:10.1016/j.enpol.2010.02.018

Orehounig, K., Evins, R., and Dorer, V. (2015). Integration of decentralized energy systems in neighbourhoods using the energy hub approach. Appl. Energy 154, 277-289. doi:10.1016/j.apenergy.2015.04.114

Osterwalder, A., and Pigneur, Y. (2010). Business Model Generation: A Handbook for Visionaries, Game Changers, and Challengers. Hoboken, NJ: Wiley. Available at: http://www.amazon.com/Business-Model-GenerationVisionaries-Challengers/dp/0470876417

Provance, M., Donnelly, R. G., and Carayannis, E. G. (2011). Institutional influences on business model choice by new ventures in the microgenerated energy industry. Energy Policy 39, 5630-5637. doi:10.1016/j.enpol.2011.04.031

Richter, M. (2012). Utilities' business models for renewable energy: a review. Renew. Sustain. Energy Rev. 16, 2483-2493. doi:10.1016/j.rser.2012.01.072

Richter, M. (2013a). Business model innovation for sustainable energy: German utilities and renewable energy. Energy Policy 62, 1226-1237. doi:10.1016/j. enpol.2013.05.038

Richter, M. (2013b). German utilities and distributed PV: how to overcome barriers to business model innovation. Renew. Energy 55, 456-466. doi:10.1016/j. renene.2012.12.052

Sagebiel, J., Müller, J. R., and Rommel, J. (2014). Are consumers willing to pay more for electricity from cooperatives? Results from an online Choice Experiment in Germany. Energy Res. Soc. Sci. 2, 90-101. doi:10.1016/j.erss. 2014.04.003

Schleicher-Tappeser, R. (2012). How renewables will change electricity markets in the next five years. Energy Policy 48, 64-75. doi:10.1016/j.enpol.2012.04.042

SFOE. (2013). Swiss Energy Strategy 2050. Available at: www.energystrategy2050. ch (accessed November 11, 2015)

Silvermann, D. (2009). Doing Qualitative Research. London: SAGE.

Sühlsen, K., and Hisschemöller, M. (2014). Lobbying the "Energiewende". Assessing the effectiveness of strategies to promote the renewable energy business in Germany. Energy Policy 69, 316-325. doi:10.1016/j.enpol.2014.02.018

Swiss Commision for Technology and Innovation. (2014). Swiss Competence Centers for Energy Research. Available at: https://www.kti.admin.ch/kti/en/ home/ueber-uns/foerderbereiche/foerderprogramm-energie.html

Tabi, A., Hille, S. L., and Wüstenhagen, R. (2014). What makes people seal the green power deal? - customer segmentation based on choice experiment in Germany. Ecol. Econ. 107, 206-215. doi:10.1016/j.ecolecon.2014.09.004

Toke, D., and Fragaki, A. (2008). Do liberalised electricity markets help or hinder CHP and district heating? The case of the UK. Energy Policy 36, 1448-1456. doi:10.1016/j.enpol.2007.12.021 
Viardot, E. (2013). The role of cooperatives in overcoming the barriers to adoption of renewable energy. Energy Policy 63, 756-764. doi:10.1016/j.enpol. 2013.08.034

Wüstenhagen, R., and Menichetti, E. (2012). Strategic choices for renewable energy investment: conceptual framework and opportunities for further research. Energy Policy 40, 1-10. doi:10.1016/j.enpol.2011.06.050

Yildiz, Ö (2014). Financing renewable energy infrastructures via financial citizen participation - the case of Germany. Renew. Energy 68, 677-685. doi:10.1016/j. renene.2014.02.038

Yildiz, Ö, Rommel, J., Debor, S., Holstenkamp, L., Mey, F., Müller, J. R., et al. (2015). Renewable energy cooperatives as gatekeepers or facilitators? Recent developments in Germany and a multidisciplinary research agenda. Energy Res. Soc. Sci. 6, 59-73. doi:10.1016/j.erss.2014.12.001
Zott, C., and Amit, R. (2013). The business model: a theoretically anchored robust construct for strategic analysis. Strateg. Organ. 11, 403-411. doi:10.1177/ 1476127013510466

Conflict of Interest Statement: The authors declare that the research was conducted in the absence of any commercial or financial relationships that could be construed as a potential conflict of interest.

Copyright (C) 2016 Facchinetti, Eid, Bollinger and Sulzer. This is an open-access article distributed under the terms of the Creative Commons Attribution License (CC $B Y)$. The use, distribution or reproduction in other forums is permitted, provided the original author(s) or licensor are credited and that the original publication in this journal is cited, in accordance with accepted academic practice. No use, distribution or reproduction is permitted which does not comply with these terms 